\title{
PENERAPAN METODE PROMETHEE DALAM SISTEM PENDUKUNG KEPUTUSAN PEMILIHAN DAUN TEMBAKAU DELI UNTUK KUALITAS EKSPOR
}

\section{IMPLEMENTATION OF PROMETHEE METHOD IN DECISION SUPPORT SYSTEM FOR DISTRIBUTION OF DELI TOBACCO LEAVES FOR EXPORT QUALITY}

\author{
Juli Iriani, Ivy Lazuli \\ Fakultas Teknik \& Ilmu Komputer \\ Jurusan Sistem Informasi Universitas Potensi Utama \\ Jl. K.L.Yos Sudarso Km 6,5 No. 3A Tanjung Mulia Medan Sumatera Utara 20241 Indonesia \\ E-mail : juli@potensi-utama.ac.id
}

\begin{abstract}
Abstrak
Tembakau Deli (Jacobus Nienhuys Deli Maatschappij) adalah Salah satu jenis tembakau yang terkenal di dunia dan dikenal juga sebagai "Dollar Land" dengan predikat sebagai penghasil daun pembungkus cerutu terbaik dunia mengalahkan tembakau dari Brazil dan Kuba. Tembakau Deli saat ini masih merupakan primadona Tembakau Cerutu. Kegunaannya lebih diutamakan untuk pembungkus cerutu. Bahkan Daun Tembakau Deli terkenal sebagai pembungkus dan pembalut cerutu nomor satu di Dunia sehingga tetap dibutuhkan oleh pabrik penghasil cerutu berkualitas tinggi. Tembakau Deli termasuk Tembakau kelas elite serta mempunyai keistimewaan lain, oleh karena itu dibutuhkan persyaratan khusus antara lain daunnya tidak boleh berlubang, tidak boleh mempunyai flek atau noda, bebas dari jamur serta ukuran panjang dan lebar daun yang sesuai dan rasanya enak serta aroma yang harum (MS Erwin, 2000). Penelitian ini bertujuan untuk membangun sebuah sistem aplikasi computer pendukung keputusan yang mempunyai kemampuan untuk menganalisa penentuan kualitas terbaik tanaman Tembakau Deli dengan menggunakan metode promethee dan memberikan keputusan terbaik berdasarkan kriteria penilaian dan alternatif yang membandingkan antara satu daun tembakau dengan daun tembakau lainnya serta menghasilkan solusi dalam pemecahan masalah. Sehingga dengan hasil yang akan dicapai akan langsung dapat menentukan daun tembakau terbaik yang akan digunakanuntuk ekspor.
\end{abstract}

Kata Kunci : daun tembakau deli, promethee, system pendukung keputusan

\begin{abstract}
Deli Tobacco (Jacobus Nienhuys Deli Maatschappij) is one of the most famous tobacco types in the world and is also known as "Dollar Land" with the predicate as the world's best cigar-leaf wrapping producer beating tobacco from Brazil and Cuba. Deli Tobacco is currently still a prima donna of Cigar tobacco. Its use is preferred for cigar wrapping. Even Deli Tobacco Leaves is known as the world's number one cigar packer and dressing so it is still needed by high quality cigar manufacturers. Deli Tobacco includes Elite grade tobacco as well as other features, therefore it requires special requirements, among others, the leaves should not be hollow, should not have spots or stains, free of fungus and the appropriate length and width of the leaves and taste good and fragrant aroma ( MS Erwin, 2000). This study aims to build a decision support computer application system that has the ability to analyze the best quality determination of Deli Tobacco plants using promethee method and provide the best decision based on assessment criteria and alternatives that compare one tobacco leaf with other tobacco leaves and produce solutions in the solution problem. So with the results to be achieved will be able to directly determine the best tobacco leaves that will be used for export.
\end{abstract}

Keyword : deli tobacco, promethee, decision support system 


\section{PENDAHULUAN}

Tembakau Deli (Jacobus Nienhuys Deli Maatschappij) adalah Salah satu jenis tembakau yang terkenal di Dunia dan dikenal juga sebagai "Dollar Land" dengan predikat sebagai penghasil daun pembungkus cerutu terbaik dunia mengalahkan tembakau dari Brazil dan Kuba.Menurut Erwin MS (2000) Tembakau Deli termasuk tembakau kelas elite serta mempunyai keistimewaan antara lain memiliki ciri, rasa dan aroma khas yang tidakdapat digantikan posisinya dengan tembakau jenis lain. Untuk itu wajar jika harga jual Tembakau Deli cukup tinggi.

Tanaman Tembakau Deli yang di panen adalah daun yang memenuhi criteria seperti elastisitas daun tembakau, memiliki aroma yang khas, warna yang dominan terang atau kuning kecoklatan serta daya bakar yang tahan lama. Kriteria tersebut secara langsung membedakan antara Tembakau Deli dengan tembakau lainnya yang kegunaannya khusus untuk pembuatan cerutu.Tembakau Deli yang layak produksi membutuhkan waktu selama satu tahun dimulai dari pembibitan, penanaman, pemetikan, proses pengolahan hingga menjadi daun tembakau deli kering serta proses pembuatan untuk cerutu. Daun Tembakau Deli yang sudah melewati test kelayakan akan di eksport ke Bremen Jerman untuk dijadikan cerutu. Selain untuk cerutu Daun Tembakau Deli juga dimanfaatkan untuk pembuatan cewing (permen) yaitu sejenis permen yang mengandung nikotin didalamnya untuk dikonsumsi para petambang emas di Amerika

\section{METODE PENELITIAN}

Penelitian ini menggunakan wawacara kepada pihak yang ahli dalam hal daun tembakau, dan wawancara yang dilakukan secara langsung berkonsultasi dengan beberapa pertanyaan yang telah disusun kepada pihak dari PTPN II untuk mendapatkan data terkait dengan penelitian daun tembakau.

\subsection{Sistem Pendukung Keputusan}

Sistem pendukung keputusan ( decision support systems disingkat DSS) adalah bagian dari sistem informasi berbasis komputer termasuk sistem berbasis pengetahuan (manajemen pengetahuan) yang dipakai untuk mendukung pengambilan keputusan dalam suatu organisasi perusahaan atau lembaga pendidikan. Menurut Moore and Chang, Sistem Pendukung keputusan dapat digambarkan sebagai sistem yang berkemampuan mendukung analisis data, dan pemodelan keputusan, berorientasi keputusan, orientasi perencanaan masa depan, dan digunakan pada saatsaat yang tidak biasa.

Kegiatan merancang sistem pendukung keputusan merupakan sebuah kegiatan untuk menemukan, mengembangkan dan menganalisis berbagai alternatif tindakan yang mungkin untuk dilakukan. Tahap perancangan ini meliputi pengembangan dan mengevaluasi serangkaian kegiatan alternatif. Sedangkan kegiatan memilih dan menelaah ini digunakan untuk memilih satu rangkaian tindakan tertentu dari beberapa yang tersedia dan melakukan penilaian terhadap tindakan yang telah dipilih.

Sistem Pendukung keputusan dirancang untuk mendukung seluruh tahap pengambilan keputusan mulai dari mengidentifikasi masalah, memilih data yang relevan, dan menentukan pendekatan yang digunakan dalam proses pengambilan keputusan, sampai mengevaluasi pemilihan alternatif

Dari pengertian Sistem Pendukung Keputusan maka dapat ditentukan karakteristik antara lain : 
1. Mendukung proses pengambilan keputusan, menitik beratkan pada management by perception.

2. Adanya tatap muka manusia / mesin dimana manusia (user) tetap memegang kendali proses pengambilan keputusan

3. Mendukung pengambilan keputusan untuk membahas masalah terstruktur, semi terstruktur dan tak struktur

4. Memiliki kapasitas dialog untuk memperoleh informasi sesuai dengan kebutuhan

5. Memiliki subsistem-subsistem yang terintegrasi sedemikian rupa sehingga dapat berfungsi sebagai kesatuan item.

6. Membutuhkan struktur data komprehensif yang dapat melayani kebutuhan informasi seluruh tingkatan manajemen.

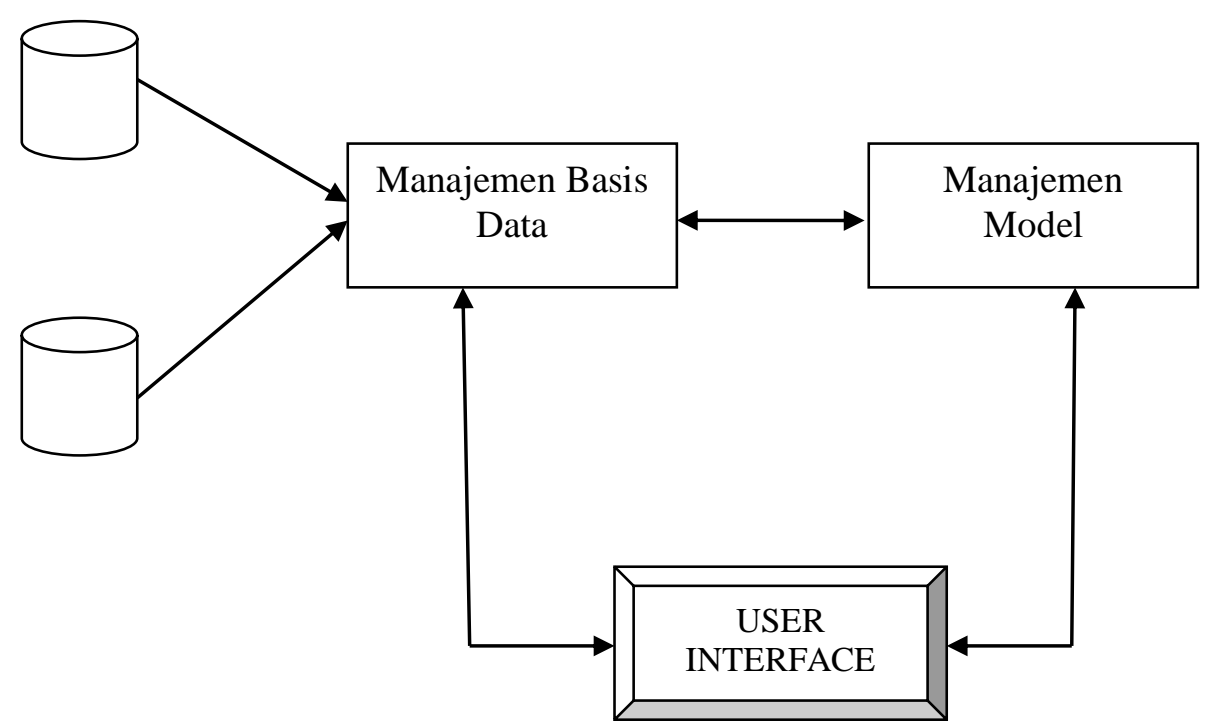

Gambar 1. Konseptual SPK

\subsubsection{Arsitektur Sistem Penunjang Keputusan}

Pada aplikasi DSS ini, memiliki komponen yang merupakan subsistem dari DSS itu sendiri yang terdiri dari:

1. Subsistem manajemen data Subsistem manajamen data memasukkan satu database yang berisi data yang untuk situasi dan dikelola oleh perangkat lunak yang disebut system manajemen database (DBMS).

2. Subsistem manajemen model merupakan paket perangkat lunak yang memasukkan model keuangan, statistik, ilmu manajemen, atau model kuantitatif yang lainnya yang memberikan kapabilitas analitik dan manajemen perangkat lunak yang tepat.

3. Subsistem antarmuka pengguna, Pengguna berkomunikasi dengan dan memerintah DSS melalui subsistem ini. Pengguna adalah bagian yang dipertimbangkan dari sistem. Para peneliti menegaskan bahwa beberapa kontribusi unik dari DSS berasal dari interaksi yang 
intensif antara komputer dan pembuat keputusan. Browser Web memberikan struktur antarmuka pengguna grafis yang familiar dan konsisten bagi kebanyakan DSS.

4. Subsistem manajemen berbasis-pengetahuan Subsistem ini dapat mendukung semua susbsistem lain atau bertindak sebagai suatu komponen independen. Ia memberikan intelegensi untuk memperbesar pengetahuan si-pengambilan keputusan. Subsistem ini dapat diinterkoneksikan dengan repositori perusahaan (bagian dari sistem manajemen pengetahuan), yang kadang-kadang disebut basis pengetahuan organisasional(kadarsah suryadi, 2002).

\subsubsection{Komponen Sistem Pendukung Keputusan}

Menurut Turban, et.,al, (2005) Sistem Pendukung Keputusan terdiri atas tiga komponen penting utama untuk menentukan kapabilitas teknis, yaitu:

1. Subsistem manajemen data, subsistem manajemen data memasukkan satu database yang berisi data yang relevan untuk situasi dan dikelola oleh perangkat lunak yang disebut sistem manajemen database (DBMS).

2. Subsistem manajemen model, merupakan paket perangkat lunak yang memasukkan model keuangan, statistik, ilmu manajemen atau model kuantitatif lainnya yang memberikan kapabilitas analitik dan manajemen perangkat lunak yang tepat.

3. Antarmuka Pengguna, pengguna berkomunikasi dengan memerintahkan DSS melalui subsistem ini.

\subsection{Promethee}

Promethee adalah suatu metode penentuan urutan (prioritas) dalam MCDM.Permasalahan utama di dalam metode ini adalah kesederhanaan, kejelasan, dankestabilan. Dugaan dari dominasi kriteria yang digunakan dalam Promethee adalahpenggunaan nilai dalam hubungan outranking. Di dalam metode ini, semua parameteryang dinyatakan mempunyai pengaruh nyata menurut pandangan ekonomi. DalamPromethee terdapat enam bentuk fungsi preferensi kriteria.Meskipun tidak bersifat mutlak, namun bentuk-bentuk ini cukup baik untuk beberapakasus. Untuk memberikan gambaran yang lebih baik terhadap area yang tidak sama,digunakan fungsi selisih nilai kriteria antara alternatif $\mathrm{H}(\mathrm{d})$, dimana hal inimempunyai hubungan langsung dengan fungsi preferensi $P$.

2.3.1 Penentuan Leaving Flow, Entering Flow dan Net Flow.

Leaving flow adalah jumlah nilai garis lengkung yang memiliki arahmenjauh dari simpul a dan ini merupakan karakter pengukuran outranking seperti terlihat pada gambar 1.

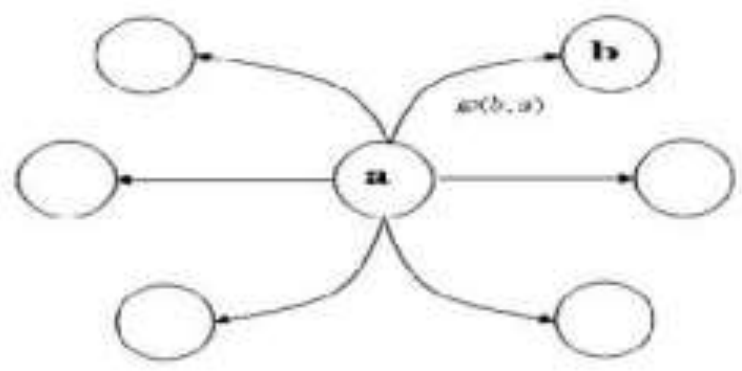

Gambar 2. leaving flow 
Langkah-langkah yang digunakan metode ini adalah sebagai :

1. Menentukan/mengidentifikasi alternatif.

2. Penjelasan kriteria, semua alternatif dievaluasi pada beberapa kriteria yang harus dimaksimalkan atau diminimalkan.

3. Rekomendasi fungsi preferensi untuk keperluan aplikasi.

4. Evaluasi matrik.

5. Perhitungan nilai preferensi dan indek preferensi.

6. Beberapa preferensi kriteria pada promethee :

\section{HASIL DAN PEMBAHASAN}

\subsection{Analisa Penerapan Prometehee}

Terdapat beberapa alternatif yang digunakan dalam menentukan daun tembakau deli yang terbaik. Alternatif yang diambil dan akan dipilih sebagai daun yang kualtias layak untuk diekspor adalah sebanyak 5 daun yang berbeda untuk perbandingan maka disebut daun1, daun2, daun3 Dalam melakukan penilaian kualitas daun, maka ditentukan beberapa kriteria yang digunakan yaitu : kriteria elastisitas, warna terang, aroma dan sortasi. Preferensi didalam metode promethee ada 6 yaitu :

1. Preferensi $\mathrm{I}=$ Kriteria biasa (Usual Criterion)

2. Preferensi II $=$ Kriteria Quasi (Quasi Criterion)

3. Preferensi III $=$ Kriteria dengan preferensi linier

4. Preferensi IV $=$ Kriteria Level (level Criterion)

5. Preferensi $\mathrm{V}=$ Kriteria dengan preferensi linier dan area yang tidak berbeda

6. Preferensi VI = Kriteria Gaussian (Gaussian Criterion).

Berdasarkan pengamatan di lapangan diperoleh data-data untuk masing-masing alternatif dan kriteria yang telah ditentukan. Pada pembahasan ini akan digunakan 3 daun sebagai sample untuk dilakukan penilaian kualitas berdasarkan kriteria yang telah ditentukan dan selanjutnya diperoleh hasil penilaian dengan metode Promethee.

Tabel 1. Data bobot kriteria

\begin{tabular}{|c|c|c|}
\hline Kriteria & Bobot & Dalam \\
\hline Elastisitas & 30 & 0.3 \\
\hline Warna terang & 30 & 0.3 \\
\hline Aroma & 30 & 0.3 \\
\hline Sortasi & 30 & 0.1 \\
\hline
\end{tabular}

Langkah selanjutnya dalam metode promethee adalah menentukan rekomendasi preferensi terhadap kriteria yang digunakan dalam melakukan penilaian terhadap data daun. Pemilihan preferensi terhadap kriteria ditentukan berdasarkan kebutuhan dan kegunaan kriteria yang akan digunakan.

Langkah selanjutnya adalah membandingkan alternatif dengan alternatif yang lain berdasarkan setiap kriteria.Perbandingan setiap alternatif : 
1. daun1 dan daun2

2. daun1 dan daun3

3. daun2 dan daun3

4.1 Perbandingan alternative daun1 dan daun2

$\begin{array}{ll}\text { a. Elastisitas } & \\ \mathrm{d}= & 0 \\ \mathrm{p}(\mathrm{a} 1, \mathrm{a} 2) & 1 \\ \mathrm{p}(\mathrm{a} 2, \mathrm{a} 1) & 0\end{array}$

b. Warna terang

$\mathrm{d}=$

$\mathrm{p}(\mathrm{a} 1, \mathrm{a} 2) \quad 1$

$\mathrm{p}(\mathrm{a} 2, \mathrm{a} 1) \quad 0$

c. Aroma

$\mathrm{d}=\quad 1$

$\mathrm{p}(\mathrm{a} 1, \mathrm{a} 2) \quad 0$

$\mathrm{p}(\mathrm{a} 2, \mathrm{a} 1) \quad 1$

d. Sortasi

$\mathrm{d}(\mathrm{a} 1, \mathrm{a} 2) \quad-2$

$\mathrm{p}(\mathrm{a} 1, \mathrm{a} 2) \quad-0,066667$

$\mathrm{d}(\mathrm{a} 2, \mathrm{a} 1) \quad-2$

$\mathrm{p}(\mathrm{a} 2, \mathrm{a} 1) \quad-0,066667$

Langkah selanjutnya adalah menentukan index preferensi berdasarkan hasil perbandinga setiap alternatif berdasarkan kriteria maka diperoleh :

Index preferensi perbandingan daun1 dan daun2 :

$\begin{array}{ll}\delta(\mathrm{a} 1, \mathrm{a} 2)= & -0,01666667 \\ \delta(\mathrm{a} 2, \mathrm{a} 1)= & 0,916666667\end{array}$ 
Index Preferensi perbandingan daun1 dan daun3:

$\delta(\mathrm{a} 1, \mathrm{a} 3)=$

0,593333

$\delta(\mathrm{a} 3, \mathrm{a} 1)=$

0,293333

Index Preferensi perbandingan daun2 dan daun3 :

$\begin{array}{ll}\delta(\mathrm{a} 2, \mathrm{a} 3)= & 0,01 \\ \delta(\mathrm{a} 3, \mathrm{a} 2)= & 0,89\end{array}$

Proses yang terakhir adalah menghitung nilai net flow dan leaving low. Hasil dari net flow dan leaving low akan menentukan rangking dari setiap alternatif.

Tabel 2. Data nilai net flow dan leaving low

\begin{tabular}{|l|l|l|l|l|l|}
\hline alternatif & Daun 1 & Daun 2 & Daun 3 & Leaving low & rangking \\
\hline Daun 1 & & 0.16667 & 0.593333 & 0.288333 & 3 \\
\hline Daun 2 & 0.916667 & & 0.01 & 0.463333 & 2 \\
\hline Daun 3 & 0.293333 & 0.89 & & 0.591667 & 1 \\
\hline Entering low & 0.605 & 0.43667 & 0.301667 & & \\
\hline Net flow & 0.316667 & 0.02667 & 0.29 & & \\
\hline Rangking net flow & 3 & 2 & 1 & & \\
\hline
\end{tabular}

Dari hasil perhitungan dengan menggunakan metode promethee bahwa daun 3 merupakan hasil kualitas yang terbaik sehingga layak untuk dijadikan sebagai kategori produk ekspor. Berikut merupakan tampilan interface system yang akan diimplementasikan :

\subsection{Tampilan laman Login} dibangun :

Berikut merupakan tampilan laman home sekaligus laman login pada system yang 

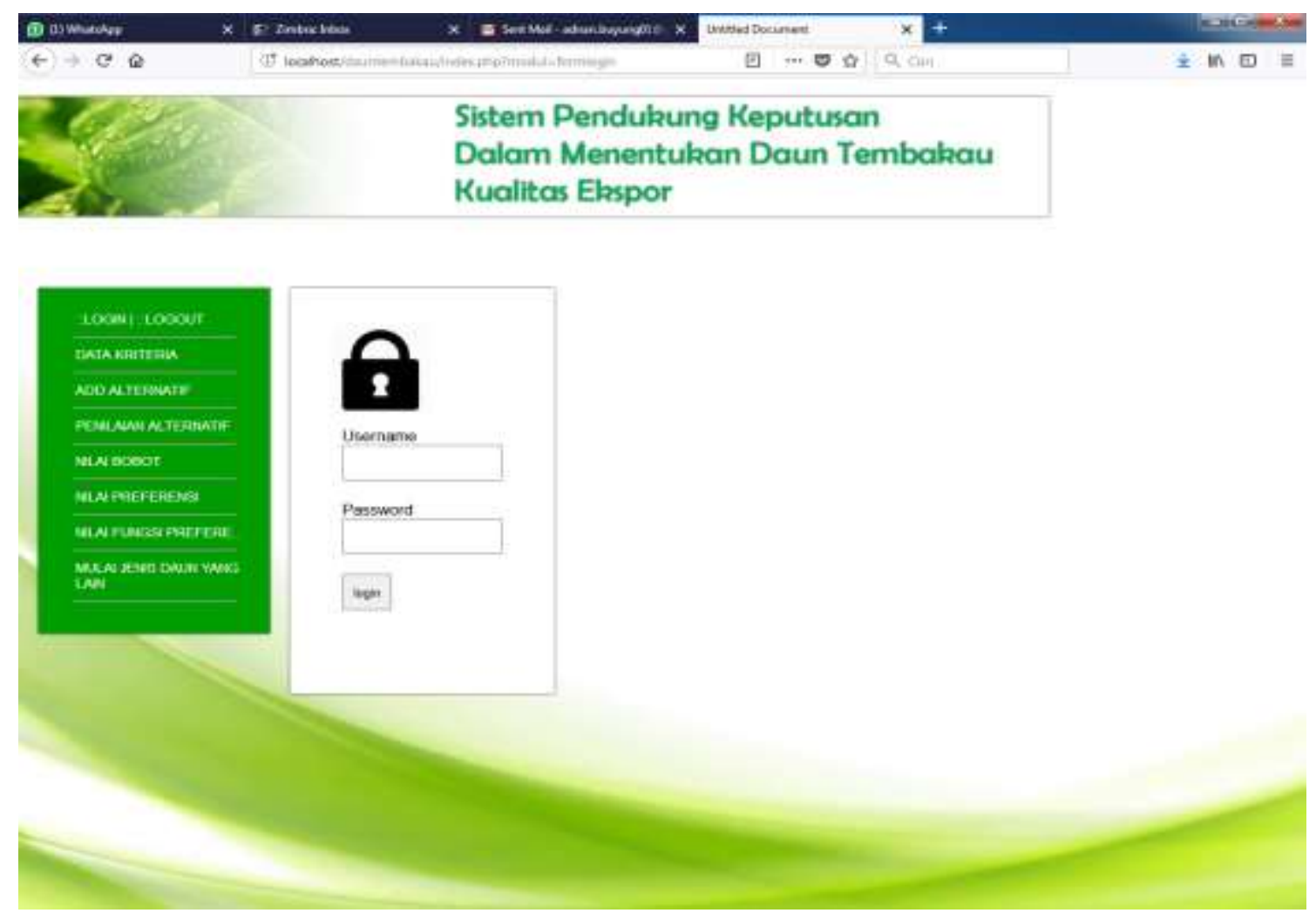

Gambar 3. Tampilan interface laman login.

Pada gambar diatas merupakan tampilan laman login yang digunakan sebagai laman untuk menerima username dan password pengguna yang nantinya akan di verifikasi oleh system jika valid maka pengguna akan ke tampilan selanjutnya.

\subsection{Tampilan laman kriteria}

Berikut merupakan tampilan laman interface kriteria pada system pendukung keputusan yang dibangun : 

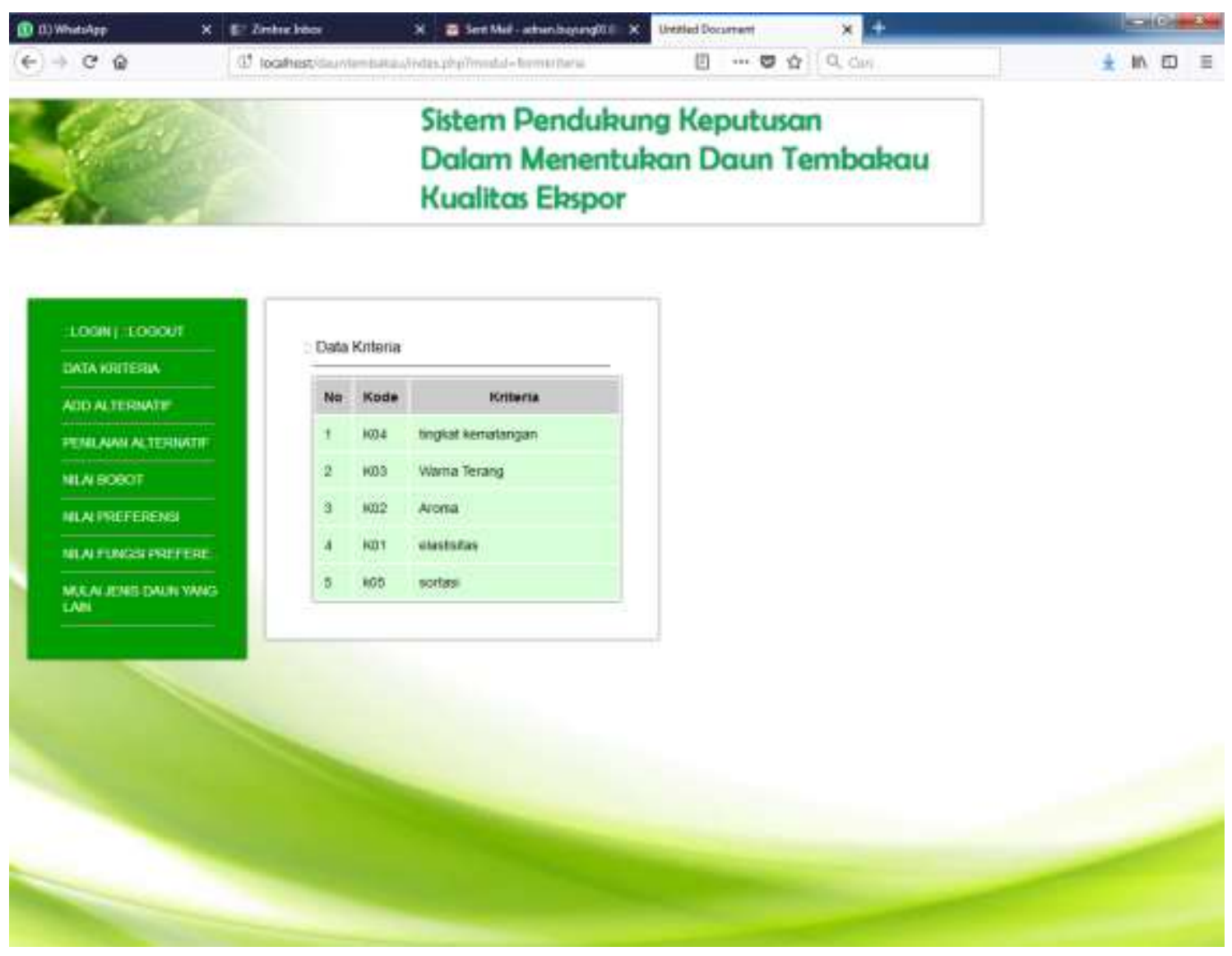

Gambar 4. Tampilan interface laman kriteria

Pada gambar diatas merupakan tampilan laman criteria yang digunakan untuk menampilkan beberapa criteria gejala pada daun tembakau dimana data tersebut ditampilkan dari databse.

\subsection{Tampilan laman alternatif}

Berikut merupakan tampilan laman interface alternatif pada system pendukung keputusan yang dibangun : 

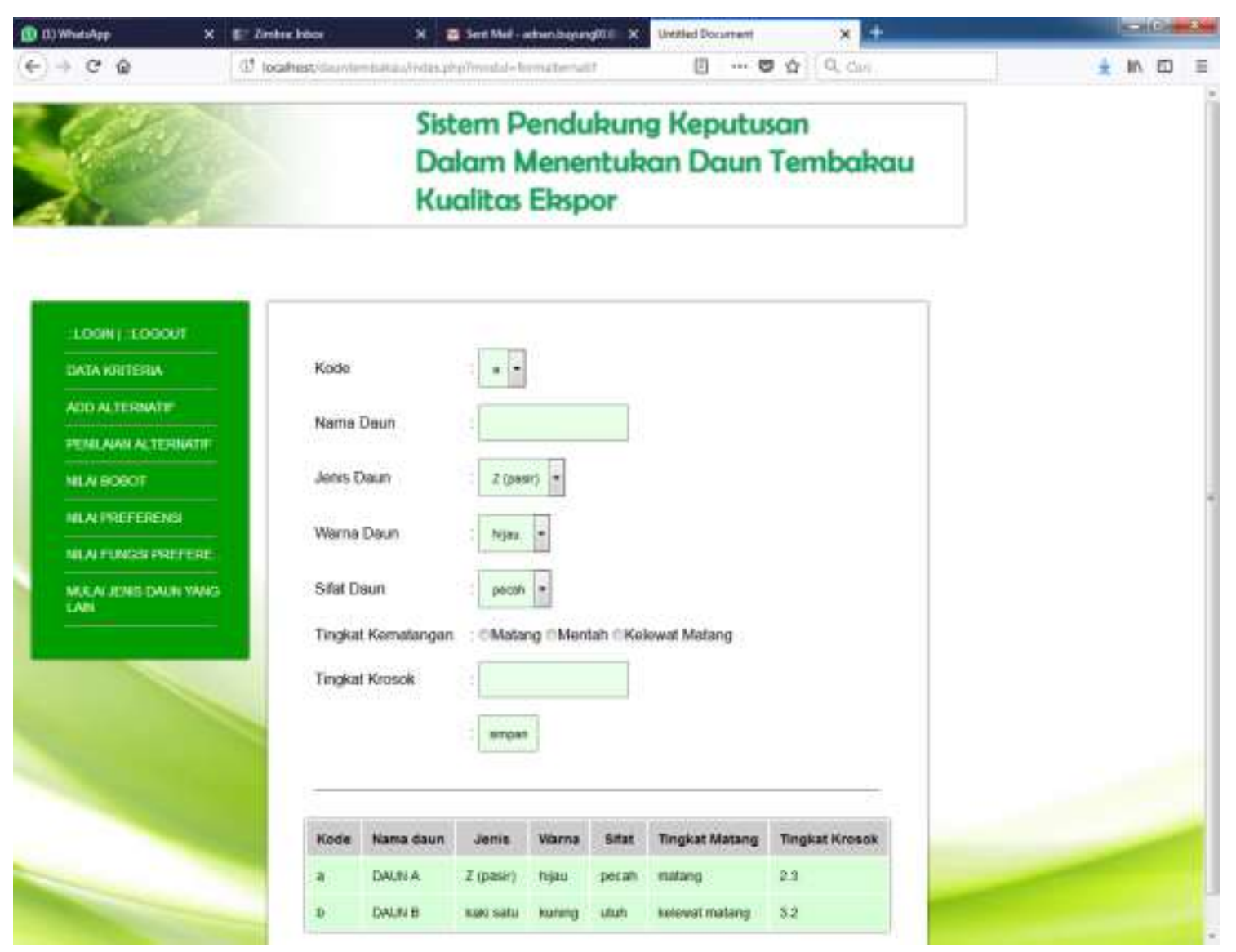

Gambar 5. Tampilan interface laman alternative

Pada gambar diatas merupakan tampilan laman alternatif yang digunakan untuk menampilkan form alternative yang terdiri dari beberapa textbox dan combo box dan submit dimana form sebagai fasilitas input data alternative untuk dikirim kedalam database selanjutnya pada laman diatas menampilkan table data alternative.

\subsection{Tampilan laman penilaian alternatif}

Berikut merupakan tampilan laman interface alternatif pada system pendukung keputusan yang dibangun : 

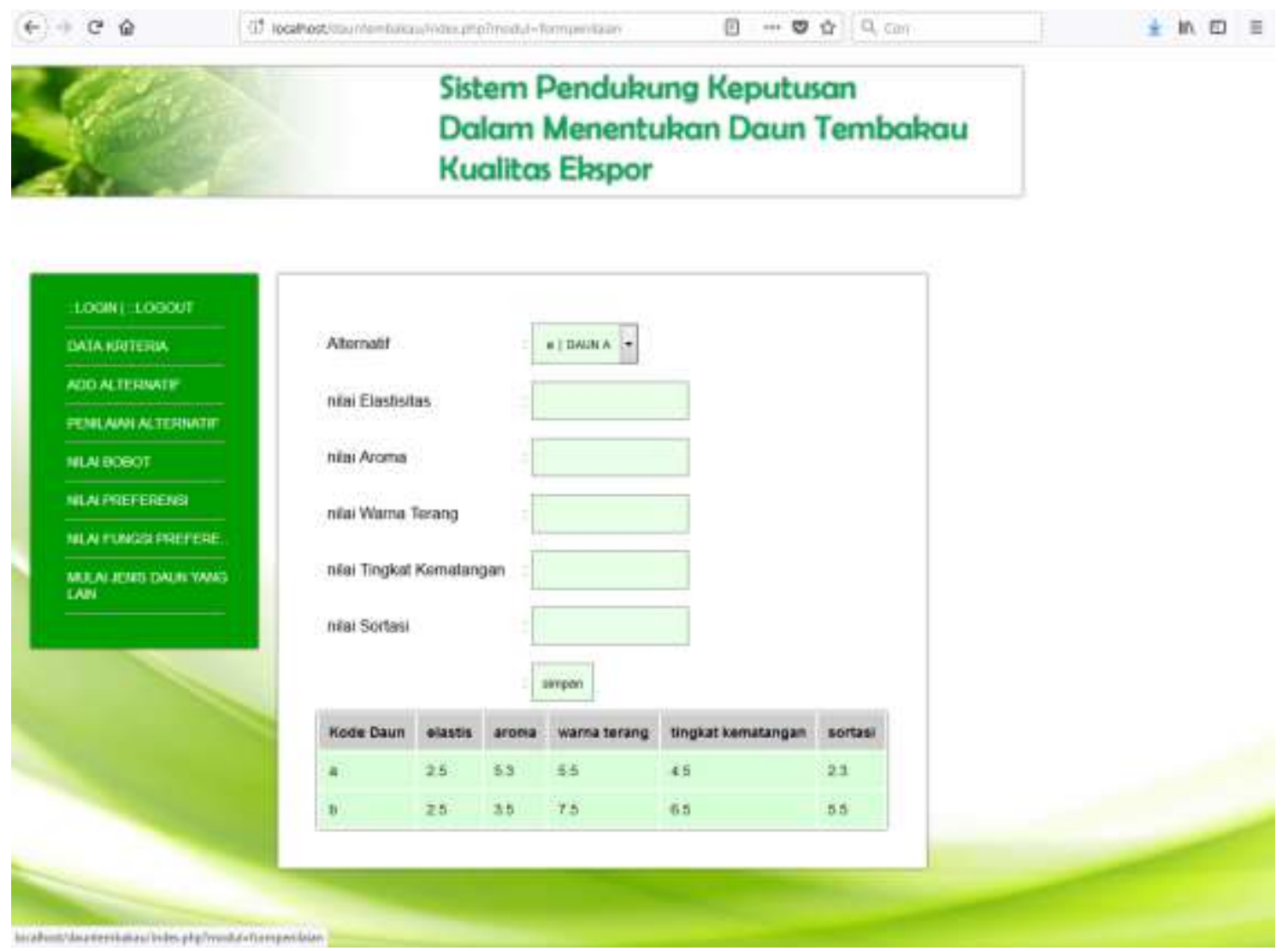

Gambar 6. Tampilan interface laman penilaian alternatif

Pada gambar diatas merupakan tampilan laman penilaian alternatif yang digunakan untuk menampilkan form penilaian alternative yang terdiri dari beberapa textbox dan combo box dan submit dimana form sebagai fasilitas input data penilaian alternative untuk dikirim kedalam database selanjutnya pada laman diatas menampilkan table data penilaian alternative.

\subsection{Tampilan laman penilaian fungsi preferensi}

Berikut merupakan tampilan laman penilaian fungsi preferensi pada system pendukung keputusan yang dibangun : 


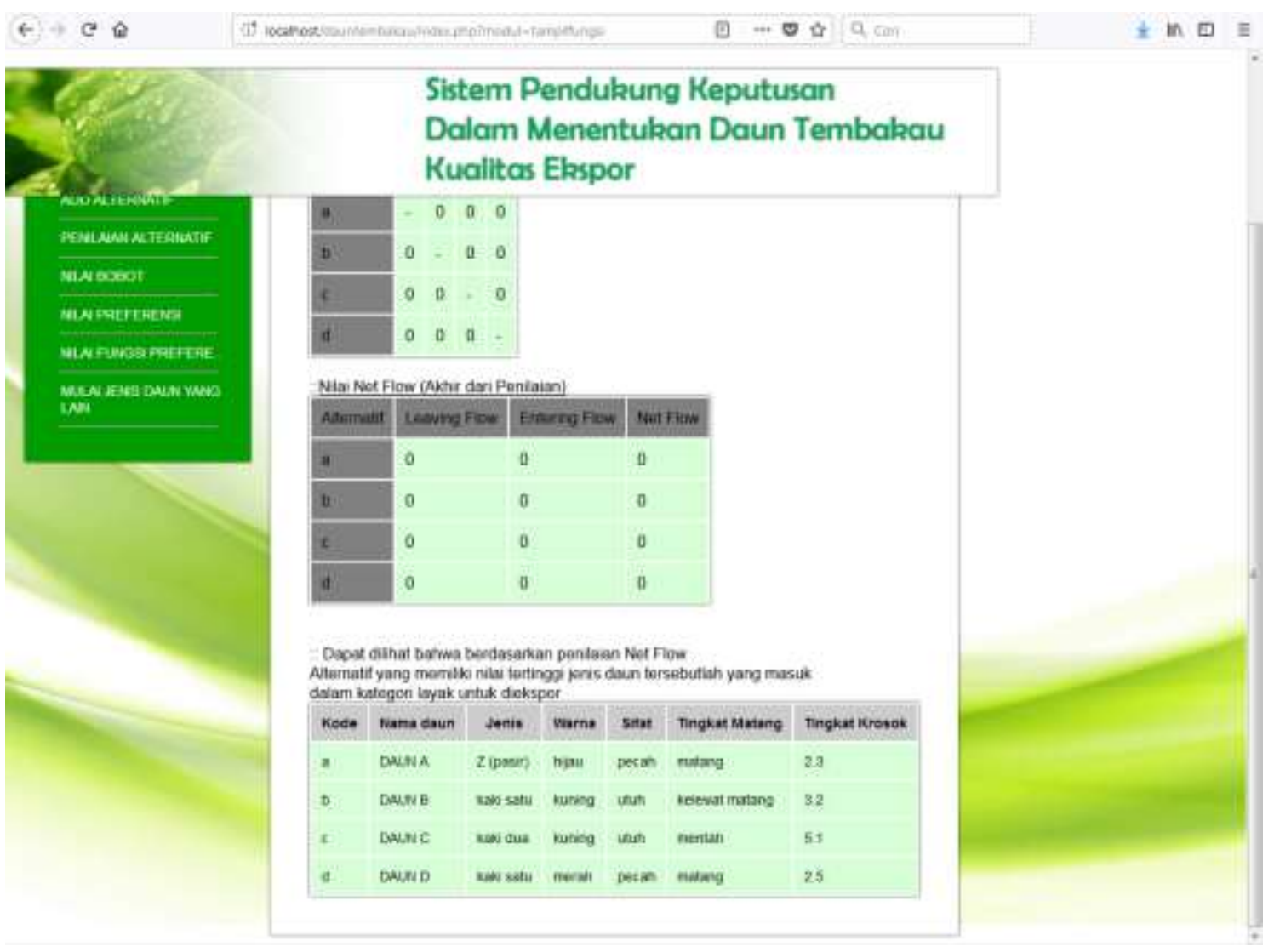

Gambar 7. Tampilan interface laman penilaian fungsi preferensi

Pada gambar diatas merupakan tampilan laman penilaian fungsi preferensi yang digunakan untuk menampilkan form penilaian fungsi preferensi yang terdiri dari beberapa textbox dan combo box dan submit dimana form sebagai fasilitas input data penilaian fungsi preferensi untuk dikirim kedalam database selanjutnya pada laman diatas menampilkan table data penilaian fungsi preferensi.

\section{KESIMPULAN}

Dengan aplikasi system pendukung keputusan yang dibangun dengan menggunakan metode Promethee ini tentunya dapat membantu untuk menyeleksi daun tembakau deli yang layak untuk ekspor dengan cepat dan tepat tanpa membutuhka waktu yang lebih lama, dan banyak menghemat waktu.

\section{UCAPAN TERIMA KASIH}

Penulis mengucapkan terima kasih kepada DRPM Ditjen Penguatan Risbang yang telah mendanai penelitian ini dan juga kepada Universitas Potensi Utama Karena telah memberikan dukungan dan perhatian terhadap penelitian ini. 


\section{DAFTAR PUSTAKA}

[1] Kusrini dan Awaludin, Sistem Pendukung Keputusan Evaluasi Kinerja Karyawan Untuk Promosi Jabatan. Yogyakarta

[2] Turban, E. 2003. Decision Support Systems and Intelegent Syatems (Sistem Pendukung Keputusan dan Sistem Cerdas) Jilid I. Yogyakarta: Andi

[3] Lynn Beighley, Michael Morrison. (2009). Head First PHP \& MySQL. United States of America: O’Reilly Media, Inc

[4] Mcleod, Jr. Raymond dan George Schell. 2001. Management Information System. Edisi Ketujuh. New Jersey : Prentice Hall International Inc.

[6] Mulyadi, 1993. Sistem Akuntansi. Edisi Ketiga. Yogyakarta : Penerbit Sekolah Tinggi Ilmu Ekonomi YKPN 